\title{
Blindness reversal in corioretinitis sclopetaria
}

\author{
Reversão da amaurose em caso de retinopatia esclopetária
}

\author{
Thaíne Garcia Cruz Carvalho', Leandro Cabral Zacharias², Carla Moreira Albhy¹, Walter Y. Takahashi
}

\begin{abstract}
Corioretinitis sclopetaria is a rare manifestation of ocular trauma which may or may not penetrate the orbit. The aim of this study is to report a case of Corioretinitis sclopetaria after orbital trauma by a firearm bullet that had initial total blindness in the affected eye, and evolved over weeks with partial visual recovery. We report a 12 years old boy, victim of firegun injury, who presented a diagnosis of corioretinitis sclopetaria in his right eye. Initial ophthalmologic examination of this eye showed nonreactive pupil and visual acuity of no light perception. The left eye was normal. The patient underwent excision of the firearm bullet located in the orbit. On the early postoperative, the patient reported seeing light and presented visual acuity of counting fingers at $30 \mathrm{~cm}$. The patient showed steady improvement and after eight months his visual acuity was of 0.15 on the affected eye. In corioretinitis sclopetaria, presented visual acuity is generally low. It is still unclear whether visual loss is caused by damage to retina, optic nerve or both components. Patients with total blindness after trauma usually have no visual prognosis. However, some patients may show visual acuity improvement, such as the case described here. Therefore, in patients victims of blunt ocular trauma with low visual acuity, including no light perception, it is important to monitor these patients and treat, if necessary, due to the possibility of visual recovery.

Keywords: Blindness; Chorioretinitis/diagnosis; Eye injuries; Wounds, gunshot; Retina/injuries; Case reports
\end{abstract}

\section{ReSUMO}

A retinopatia esclopetária é uma manifestação rara de trauma ocular que pode ou não penetrar a órbita. O objetivo desse trabalho é relatar um caso de retinopatia esclopetária após trauma orbitário por bala de arma de fogo com amaurose total inicial no olho acometido, que evoluiu ao longo de semanas com recuperação visual parcial. Relatamos um caso de um paciente com 12 anos, sexo masculino, vítima de ferimento por arma de fogo, que apresentava ao exame oftalmológico inicial do olho direito pupila não reagente com acuidade visual (AV) de sem percepção luminosa (SPL) e diagnóstico de retinopatia esclopetária nesse olho. O olho esquerdo apresentava-se normal. O paciente foi submetido à exérese do projétil alojado na cavidade orbitária. No $14^{\circ}$ pós-operatório, o paciente referiu enxergar claridade, apresentava AV de conta dedos a $30 \mathrm{~cm}$. Ao longo dos primeiros meses, o paciente apresentou melhora constante da AV e com oito meses de seguimento, apresentava AV de 0,15. Na retinopatia esclopetária, a AV geralmente é baixa. Ainda não é claro atualmente se a perda visual é ocasionada por lesão à retina, ao nervo óptico, ou um misto dos dois componentes. Casos de amaurose total após trauma geralmente não apresentam prognóstico visual. Porém, alguns pacientes podem apresentar melhora da AV, como no caso aqui descrito. Conclui-se assim que em casos traumáticos contusos em pacientes com baixa AV inclusive SPL, deve-se acompanhar esses pacientes e tratar, se necessário, pela possibilidade de recuperação visual.

Descritores: Cegueira; Coriorretinite/diagnóstico; Traumatismos oculares; Ferimentos por arma de fogo; Retina/lesões; Relatos de casos

\footnotetext{
${ }^{1}$ Medical Residency Programme, Ophthalmology Department, Medical School of the São Paulo University, São Paulo/SP, Brazil. ${ }^{2}$ Retina Unit, Ophthalmology Department, Medical School of the São Paulo University, São Paulo/SP, Brazil.

${ }^{3}$ Ophthalmology Department, Medical School of the São Paulo University, São Paulo/SP, Brazil.
}

Work conducted at the Ophthalmology Department, Medical School of the São Paulo University, São Paulo/SP, Brazil.

The authors declare no conflicts of interest

Received for publication: 12/6/2014 - Accepted for publication: 11/7/2014

Rev Bras Oftalmol. 2014; 73 (6): 383-5 


\section{INTRODUCTION}

$\mathbf{S}$ everal retinal and choroidal lesions can arise after a blunt eye trauma caused by a firearm. Chorioretinitis sclopetaria has been traditionally associated with orbital trauma by a high-speed projectile that hits the orbit but does not penetrate the eye globe ${ }^{(1,2)}$,causing a full-thickness chorioretinal lesion and associated visual loss.(3)

In 1901 Goldzieher introduced the term chorioretinitis sclopetaria to describe the appearance of choroidal and retinal tearsafter orbital trauma caused by a firearm projectile. ${ }^{(1)}$

Findings on fundus examination include fibrovascular proliferation, retinal pigment epithelium (RPE) migration and proliferation, epiretinal membrane formation, loss of photoreceptors, and optic atrophy. ${ }^{(2-4)}$ Retinal detachment is rare in this condition because of the fibrovascular proliferation and scarringarising over the course of the disease. ${ }^{(3)}$

Chorioretinitis sclopetaria has been typically reported after trauma by high-speed projectiles that enter the orbit but do not penetrate the eye globe.However, it has also been described after other types of blunt trauma that do not penetrate the orbit, such as trauma by paintballsand airbags, among others. Thus, chorioretinitis sclopetaria is a rare manifestation of eye trauma with or without penetration of the orbit. ${ }^{(4)}$

The aim of this paper is to report a case of chorioretinitis sclopetaria after orbital trauma due to a firearm bullet that initially caused complete blindness, followed by partial visual recovery over the course of a few weeks.

\section{Case report}

A 12-year-old male patient was admitted to our unit with a firearm wound in his face.The entry wound was on the right upper eyelid, and there was no exit wound.The patient was clinically stable. On examination, his right eye showed oedema, haematoma, and upper eyelid laceration.On palpation, part of the projectile could be felt in the upper orbit.The patient had a non-reactive right pupil, and his visual acuity (VA) was no light perception (NPL).Biomicroscopy found significant chemosis, a formed anterior chamber with lower hyphema, and corectopia.Ocular tonus was normal.There was no ocular perforation.External ocular motility was partially reduced in all positions.Fundus examination was initially difficult due to eyelid oedema and chemosis.Examination of the left eye was normal.Tomography of the orbits found a firearm bullet lodged in the upper anterior orbit of the right eye.Removal of the bullet with surgical exploration of upper sclerawas indicated, given the possibility of perforation, with suture of the eyelid laceration.The patient underwent excision of the firearm projectile.Surgical exploration was performed and found no evidence of ocular perforation; the upper eyelid was sutured.On the first postoperative day the patient's VA was still NLP, with intense eyelid oedema, mild hyphema, upper nasal iridodialysis, and normal ocular tonus.Fundus examination was difficult due to the significant eyelid oedema. On the $14^{\text {th }}$ postoperative day the patient reported seeing light.On examination his visual acuity was counting fingers at $30 \mathrm{~cm}$ in the upper visual field, improved eyelid oedema, an intraocular pressure (IOP) of $18 \mathrm{mmHg}$, and intense inflammatory reaction in the anterior chamber.Fundus examination found a pale optic nerve without oedema and retinal pigmentary changes throughout the posterior pole (Figure 1).Oral prednisone $30 \mathrm{mg}$ per day $(1 \mathrm{mg} / \mathrm{kg})$ was prescribed.On the $21^{\text {st }}$ postopera-

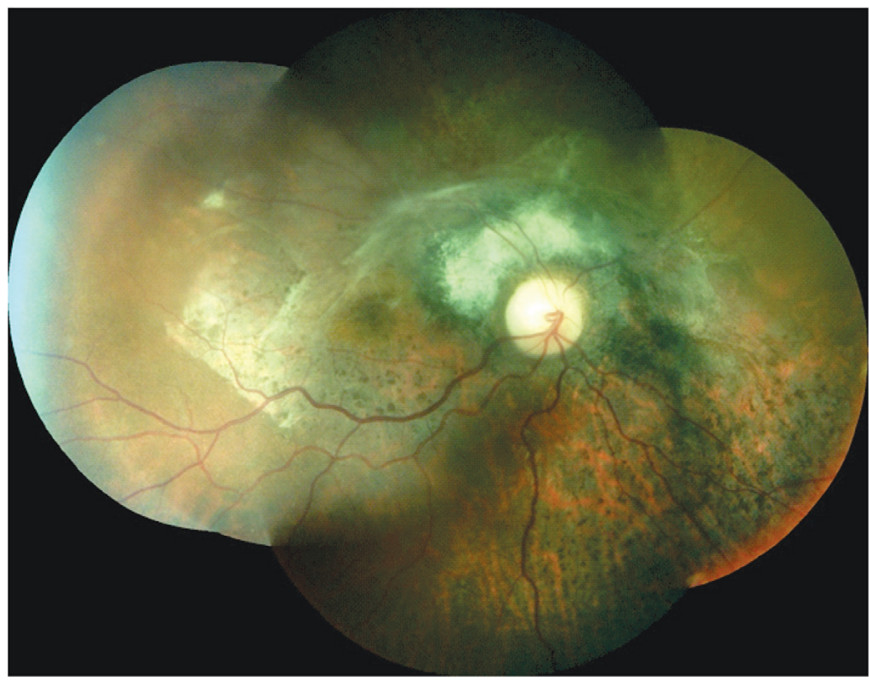

Figure 1. Chorioretinitis sclopetaria:initial retinography of the right eye

tive day the patient's VA remained unchanged, with slight improvement of intraocular inflammation. The oral prednisone was stopped.One month after surgery the patient reported visual improvement.His VA was counting fingers at one metre, with reduced anterior chamber inflammation.Fundus examination remained unchanged.After 2 months the patient again presented visual improvement.Examination found a VA of counting fingers at 1.5 metres without anterior chamber inflammation; the patient also hadupper nasal iridodialysis, mild posterior subcapsular cataract, and an unchanged fundus examination.After 4 months of follow-upthe patienthad a visual acuity of 0.1; biomicroscopy was unchanged, and fundus examination found upper temporal epiretinal membrane formation with slight traction, extensive subretinal fibrosis, and preretinal fibrosis at the 12 o'clock position.After 8 months his VA was 0.15 , and the remainder of the examination remained unchanged.

\section{Discussion}

Trauma caused by a firearm bullet can lead to penetrating or blunt eye injury.It is important to rule out penetrating lesions, as these need to be repaired surgically.Various traumatic injuries are associated with blunt trauma, such as hyphema, vitreous haemorrhage, commotio retinae, retinal detachment, optic neuropathy, and chorioretinitis sclopetaria, among others.In this paper we report the case of a patient injured by a firearm bullet that entered the orbit but did not penetrate the eye globe, leading to visual loss due to chorioretinitis sclopetaria probably associated with some degree of traumatic optic neuropathy. ${ }^{(5)}$

Eye trauma is more common in young men, similar to most types of trauma.In cases of chorioretinitis sclopetaria, some degree of hyphema and vitreous haemorrhage are commonly found.As the haemorrhage is reabsorbed, fibrous proliferation can be observed in the affected region. ${ }^{(3,4)}$

Retinal damage is attributed to a shock wave that propagates as the projectile moves at high speed. ${ }^{(3)}$ This shock wave causes chorioretinal tears, which are responsible for the diffuse scarring seen in the lesion.

The macula is commonly involved in cases of chorioretinitis sclopetaria, and some degree of traumatic optic neuropathy 
is usually present.Visual acuity is generally low due to macular scarring, macular hole, epiretinal membrane formation, and indirect damage to the optic nerve. ${ }^{(3,6)}$

In the case presented here the patient initially had a visual acuity of no light perception, which gradually improved over time.Cases of visual recovery weeks after an initial VA of NLP are well described in the literature after traumatic optic neuropathy. ${ }^{(3,5,7)}$

In this case, the patient had an initialvisual acuity of no light perception that partially improved during follow-up.Cases of isolated traumatic optic neuropathy with a visual acuity of no light perception that improves over weeks are rare, but have been reported.Reversal of total blindness after chorioretinitis sclopetaria has never been reported in our midst.It is therefore concluded that some cases of trauma can have a good visual prognosis even when presenting with NLP, as seen in this case of chorioretinitis sclopetaria.

\section{REFERÊNCIAS}

1. Goldzieher W. Beitrag zur Pathologie der orbitalen Schussverletzungen. Z Augenheilkd.1901;6:277-85.
2. Mohammadpour M, Soheilian M. Concomitant optic nerve transection and chorioretinitis sclopetaria. BMC Ophthalmol. 2005;5(1):29.

3. Ahmadabadi M N, Karkhaneh R, Roohipoor R, Tabatabai A, Alimardani A. Clinical presentation and outcome of chorioretinitis sclopetaria: a case series study. Injury. 2010; 41(1):82-5.

4. Taban M, Sears JE. Ocular findings following trauma from paintball sports. Eye (Lond). 2008; 22(7):930-4.

5. Wu W, Sia DI, Cannon PS, Selva D, Tu Y, Qu J. Visual acuity recovery in traumatic optic neuropathy following endoscopic optic nerve decompression: a case report. Ophthal Plast Reconstr Surg. 2011;27(1):e13-e15.

6. Martin DF, Awh CC, McCuen 2nd BW, Jaffe GJ, Slott JH, Machemer R. Treatment and pathogenesis of traumatic chorioretinal rupture (sclopetaria). American journal of ophthalmology. 1994; 117(2), 190-200.

7. Wolin MJ, Lavin PJ. Spontaneous visual recovery from traumatic optic neuropathy after blunt head injury. Am J Ophthalmol. 1990;109(4):430-5.

\section{Corresponding author:}

Thaíne Garcia Cruz Carvalho

RuaTeodoro Sampaio, 363, apto 505.

CEP:05405000, São Paulo/SP, Brazil

Email: thainegarcia@hotmail.com 